\title{
MEMBANGUN BUDAYA LITERASI BAGI SUPLEMEN PENDIDIKAN DI INDONESIA
}

\author{
Meidawati Suswandari \\ PGSD FKIP Universitas Veteran Bangun Nusantara Sukoharjo \\ E-mail: moetis_meida@yahoo.co.id
}

\begin{abstract}
Abstrak
Tujuan penelitian ini yaitu: 1) mendeskripsikan factor-faktor yang mempengaruhi budaya literasi, 2) peran keluarga, sekolah dan pemerintah dalam membangun budaya literasi dalam dunia pendidikan di Indonesia. Penelitian ini dilakukan melalui studi pustaka dengan mengumpulkan sejumlah buku-buku, makalah, jurnal, lefleat, majalah yang berkenaan dengan masalah litersi di Indonesia. Analisis data menggunakan analisis deskriptif, analisis isi, dan analsisis kritis. Hasil penelitian menunjukan bahwa: 1) faktor pertama yang mempengaruhi budaya/kebiasaan literasi/kemampuan membaca pada diri seseorang yaitu pada factor internal berupa diri sendiri. Faktor kedua yaitu faktor ekternal seperti stimulasi dari lingkunga keluarga dan lingkungan pendidikan, dalam hal ini guru dan perpustakaan. 2) peran keluarga, sekolah dan pemerintah membangun budaya literasi dalam pendidikan meliputi: menumbuhkan minat baca sedini mungkin, melalui subsidi buku, mengoptimalkan peran perpustakaan daerah, menghargai karya tulis serta mendapat dukungan politik dari Pemerintah dan DPR.
\end{abstract}

Kata kunci : budaya Literasi, pendidikan Indonesia

\begin{abstract}
Abstrack
The purpose of this research are: 1) to describe factors influencing culture of literasi, 2) role of family, school and government in building culture of literasi in educational world in Indonesia. This research is done through literature study by collecting a number of books, papers, journals, lefleat, magazines related to litersi problem in Indonesia. Data analysis using descriptive analysis, content analysis, and critical analysis. the results showed that 1) factors that affect the culture or the habit of literacy and the ability to read on self sesseorang is an internal factor of self. external factors such as simulation of the family environment and educational environment, in this case the teacher and the library. 2) family roles of family, school and government roles to build a culture of literacy in education include: fostering reading interest as early as possible, through book subsidies, optimizing the role of regional libraries, appreciating papers and getting political support from the Government and Parliament.
\end{abstract}

Keyword: culture Literacy, education of Indonesia

\section{PENDAHULUAN}

Pohon dapat tumbuh subur jika diberi pupuk yang cukup sebagai asupan nutrisi terbaik. Pemberian pupuk yang cukup dan rutin mampu menjaga kekuatan pohon hingga ke akarnya. Kekokohan akar pohon dapat mencegah tumbangnya pohon yang diterpa angin. Begitu pula yang terjadi hubungan antara siswa dan dunia literasi. Literasi menjadi suplemen utama untuk mengembangkan daya nalar, 
pola pikir, dan kekritisannya. Demikian juga dengan adanya literasi yang harus dibudayakan.

Budaya literasi di Indonesia menjadi persoalan yang sangat menarik untuk diperbincangkan. Mengingat budaya literasi di Indonesia masih rendah dan belum mendarah daging dikalangan masyarakat. Ditengah melesatnya budaya populer, buku tidak pernah lagi menjadi prioritas utama. Bahkan masyarakat lebih mudah menyerap budaya berbicara dan mendengar, dari pada membaca kemudian menuangkannya dalam bentuk tulisan. Masyarakat Indonesia masih lebih banyak didominasi oleh budaya komunikasi lisan atau budaya tutur. Masyarakat cenderung lebih senang menonton HP dengan update status dan mengikuti siaran televisi daripada membaca.

Literasi sendiri secara sederhana diartikan sebagai kemampuan membaca dan menulis. Dalam konteks pemberdayaan masyarakat, literasi mempunyai arti kemampuan memperoleh informasi dan menggunakannya untuk mengembangkan ilmu pengetahuan yang bermanfaat bagi masyarakat. Budaya membaca dan menulis pada masyarakat Indonesia sampai menghadapi milenium baru ini sebenarnya masih sangat memprihatinkan. Buku-buku pelajaran tidak lagi menjadi teman setia pelajar masa kini. Budaya membaca, menulis dan berdiskusi tak lagi menjadi ciri khas pelajar yang konon sering disebut sebagai generasi penerus bangsa ini. Padahal ada pepatah yang mengungkapkan bahwa buku adalah gudangnya ilmu dan membaca adalah kuncinya.

Sebuah laporan penelitian yang menempatkan Indonesia pada posisi 60 dari 61 negara. Indonesia hanya setingkat lebih tinggi darii Botswana, sebuah negara miskin di Afrika. Penelitian di bidang literasi yang dilakukan oleh Central Connecticut State University di New Britain, Conn, Amerika Serikat, menempatkan lima negara pada posisi terbaik yaitu Finlandia, Norwegia, Islandia, Denmark, dan Swedia (The Jakarta Post, 12 Maret 2016). Berdasarkan sensus Badan Pusat Statistik (BPS), seperti ditulis selasar.com 29-5-2015, pada tahun 2006 menunjukkan 85,9 \%masyarakat memilih menonton televisi daripada mendengarkan radio (40,3 persen) dan membaca koran (23,5 persen). Kita belum terbiasa melakukan sesuatu berdasarkan pemahaman dari membaca. Kita belum 
dapat mengaktualisasikan diri melalui tulisan. Membaca dan menulis belum mengakar kuat dalam budaya bangsa kita. Masyarakat lebih sering menonton atau mendengar dibandingkan membaca apalagi menulis.

Budaya membaca buku sampai saat ini masih rendah. Berdasarkan data UNESCO, persentase minat baca Indonesia sebesar 0,01 persen. Sedangkan ratarata indeks tingkat membaca di negara-negara maju berkisar antara 0,45 hingga 0,62 . Kondisi ini tentu saja sangat memprihatinkan, hal ini menempatkan Indonesia pada posisi 124 dari 187 negara dalam penilaian Indeks Pembangunan Manusia (IPM). Taufiq Ismail pernah melakukan penelitian. Pada tahun 1996 menemukan perbandingan tentang budaya baca di kalangan pelajar, rata-rata lulusan SMA di Jerman membaca 32 judul buku, di Belanda 30 buku, Rusia 12 buku, Jepang 15 buku, Singapura 6 buku, Malaysia 6 buku, Brunei 7 Buku, sedangkan Indonesia 0 buku (http://amirudinmahmud.blogspot.co.id/).

Gambaran mengenai rendahnya minat baca ini juga tidak terlalu jauh berbeda dengan keadaan masyarakat dewasa ini. Indikator yang dapat dipergunakan adalah dengan melihat jumlah surat kabar yang dikonsumsi oleh masyarakat. Idealnya, setiap surat kabar dikonsumsi oleh 10 orang, jadi satu surat kabar dibaca oleh sepuluh orang, tetapi yang ada di Indonesia adalah satu surat kabar dibaca oleh 45 orang. Bandingkan dengan negara Srilanka yang surat kabarnya dibaca oleh 38 orang per satu surat kabar. Menurut penelitian yang merupakan temuan muktahir ternyata belanja surat kabar di Indonesia hanyalah sekitar Rp. 1,9 trilyun, sementara belanja rokok di Indonesia mencapai angka Rp.47 trilyun pertahun.

Lebih ironis lagi, sebuah fakta yang diungkapkan Badan Pusat Statistika (BPS) pada survey tahun 2012 memaksa kita menghela nafas lebih panjang. Pasalnya, tren minat baca masyarakat Indonesia ternyata turun dari tahun ke tahun. Pada 2003 sebanyak 23,70 \% masyarakat Indonesia memilih menghabiskan waktu dengan membaca. Angka itu menurun pada tahun 2006 menjadi 23,46 \% dan terus menurun hingga pada 2012 hanya 17,66 \% yang gemar membaca. Survey yang sama juga membuktikan bahwa masyarakat kita ternyata lebih memilih menghabiskan waktu dengan menonton televisi $(91,68 \%)$, olahraga $(24,57 \%)$ dan mendengarkan radio $(18,57 \%)$ daripada membaca. 
Data BPS yang dikutip pada Republika, 12 September 2015 bahwa jumlah rata-rata waktu yang digunakan anak Indonesia dalam menonton televisi adalah 300 menit per hari. Jumlah ini jauh lebih besar dibanding anak-anak di Australia yang hanya 150 menit per hari dan di Amerika yang hanya 100 menit per hari, apalagi di Kanada yang hanya 60 menit per hari.

Data di atas menunjukkan bahwa masyarakat Indonesia kita lebih suka mendapatkan informasi dari media elektronik, terutama televisi. Masyarakat kita berlaku sebagai "pembaca pasif" yang mendapatkan informasi dengan tenang mengunyah renyah segala persepsi yang dikemukakan di televisi. Sehingga persepsi yang ada dalam masyarakat, selalu berdasarkan persepsi dari televisi. Fenomena itu disebut sebagai kelisanan sekunder (secondary orality). Budaya kelisanan sekunder tersebut menggambarkan bahwa Badan Pusat Statistik (BPS), adalah Lembaga Pemerintah Non Departemen di Indonesia yang mempunyai fungsi pokok sebagai penyedia data statistik dasar, baik untuk pemerintah maupun untuk masyarakat umum, secara nasional maupun regional. Setiap sepuluh tahun sekali, BPS menyelenggarakan sensus penduduk. Di samping itu, BPS juga melakukan pengumpulan data, menerbitkan publikasi statistik nasional maupun daerah, serta melakukan analisis data statistik yang digunakan dalam pengambilan kebijakan pemerintah (Julia, 2011).

Bahkan di kalangan anak sekolah, anak yang rajin membaca justru diolokolok dengan sebutan "kutu buku". Seolah-olah kebiasaan membaca sebagai hal yang aneh. Persepsi inilah yang sesungguhnya telah berakibat buruk terhadap sistem pendidikan di tanah air. Membangun pendidikan berarti membangun masa depan bangsa melalui penyiapan sumber daya manusia yang sesuai dengan tuntutan zaman. Namun ironisnya, pendekatan yang dilakukan untuk itu menggunakan pendekatan lama yang tidak sesuai dan tidak signifikan dengan tantangan masa depan itu.

Akibatnya penyiapan sumber daya yang unggul hanya menjadi wacana. Beberapa hal yang menjadikan rendahnya budaya literasi di Indonesia antara lain, tingkat pendidikan masyarakat, malas membaca, minimnya akses dalam membaca. Ini disebabkan sedikitnya perpustakaan, harga buku yang cenderung tak terjangkau 
oleh daya beli masyarakat dan pemamfaatan teknologi yang tidak tepat, sehingga hanya sedikit yang mampu menuliskan pengetahuan yang diperoleh dari membaca atau menyimak. Di tengah kemajuan teknologi saat ini, seharusnya kegiatan membaca dan menulis sebagai akar membangun budaya literasi menjadi semakin mudah. Seperti halnya pemanfaatan internet.

Internet dapat digunakan dalam mengakses informasi tertulis maupun sarana meningkatkan kemampuan menulis. Seperti website dan blog mudah ditemukan dan dibuat, e-paper dan e-book gampang diakses. Namun, jika tidak disikapi dengan bijak internet malah menjadi tempat membuang waktu karena tidak digunakan secara efektif dan produktif. Padahal jika internet dipakai untuk membaca atau mencari bahan untuk menulis akan menjadi hal yang sangat berguna. Selain itu ketidaktegasan pemerintah untuk menindak media yang belakangan ini menampilkan tayangan-tayangan yang tidak mendidik bahkan bertentangan dengan norma semakin membuat media berani untuk menampilkan tayangan-tayangan yang tidak bermanfaat dan bermartabat. Begitu banyak tayangan-tayangan hiburan di media yang tidak mendidik bahkan berbahaya.

\section{METODE PENELITIAN}

Penelitian ini dilakukan melalui studi pustaka dengan mengumpulkan sejumlah buku-buku, makalah, jurnal, lefleat, majalah yang berkenaan dengan masalah pendidikan aliran klasik. Data yang diperoleh berasal dari dokumen pribadi yang berupa bahan-bahan orang yang mengucapan dengan kata-kata mereka sendiri (Arief Furqon, 1992: 23). Sehingga dalam pengumpulan data dengan mengidentifikasi wacana dari buku-buku, makalah atau artikel, majalah, jurnal, Koran, internet (web), ataupun informasi lainnya yang berhubungan dengan aliran pendidikan klasik. Adapun analisis data menggunakan analisis deskriptif, analisis isi, dan analsisis kritis. Analisis deskriptif yaitu mengumpulkan dan menyusun data kemudian dianalisis data tersebut. Analisis isi yaitu memanfaatkan seperangkat prosedur untuk menarik kesimpulan dari sebuah dokumen yang telah diperoleh. Sementara itu analisis kritis yaitu penafsiran pada teks dan menyikapi makna dibalik suatu peristiwa secara ilmiah. 


\section{HASIL DAN PEMBAHASAN}

Peran keluarga memegang andil besar dalam terciptanya budaya literasi pada anak-anak Indonesia, terutama peran orang tua. Kurangnya peran orang tua dalam pengawasan dan penanaman kebiasaan membaca dan menulis pada anaknya juga salah satu faktor merosotnya budaya literasi. Orang tua lebih sibuk dengan pekerjaan dan kegiatannya tanpa mengikuti tahap-tahap perkembangan pendidikan anaknya. Padahal lingkungan keluarga terutama orang tua lah yang dianggap mempunyai peran besar dalam membimbing anaknya untuk menanamkan budaya membaca dan menulis.

Sementara itu menurut Ridwan (2004) minat membaca adalah keinginan atau kecenderungan hati yang tinggi (gairah) untuk membaca. Minat membaca didukung oleh sarana dan prasarana untuk membaca akan menumbuhkan kebiasaan membaca (reading habit), dan selanjutnya akan berkembang menjadi budaya baca dalam masyarakat. Minat baca dapat dipupuk, dibina dan dikembangkan karena minat baca adalah suatu keterampilan yang diperoleh setelah seseorang dilahirkan, bukan keterampilan bawaan.

Kamus Besar Bahasa Indonesia (2001: 129), "kebiasaan adalah sesuatu yang biasa dilakukan, kebiasaan juga berarti pola untuk melakukan tanggapan terhadap situasi tertentu yang dipelajari oleh seorang individu dan yang dilakukannya secara berulang untuk hal yang sama". Kebiasaan bukanlah sesuatu yang alamiah dalam diri manusia tetapi merupakan hasil proses belajar dan pengaruh pengalaman dan keadaan lingkungan sekitar. Karena itu kebiasaan dapat dibina dan ditumbuhkembangkan.Sedangkan membaca merupakan suatu proses komunikasi ide antara pengarang dengan pembaca, dimana dalam proses ini pembaca berusaha menginterpretasikan makna dari lambanglambang atau bahasa pengarang untuk menangkap dan memahami ide pengarang. Maka kebiasaan membaca adalah kegiatan membaca yang dilakukan secara berulangulang tanpa ada unsur paksaan. Kebiasaan membaca mencakup waktu untuk membaca, jenis bahan bacaan, cara mendapatkan bahan bacaan, dan banyaknya buku/bahan bacaan yang dibaca (Hendro P dan M.Habibburahman, 2015). 
Namun demikian kemampuan membaca pada diri seseorang bukan jaminan bagi terciptanya kebiasaaan membaca karena kebiasaan membaca juga dipengaruhi oleh faktor lainnya (Winoto, 1994: 151) misalnya ketersediaan bahan bacaan. Perkembangan kebiasaan melakukan kegiatan merupakan proses belajar yang dipengaruhi oleh faktor internal dan eksternal. Gould (Ferrinadewi, Erna \& Didit Darmawan, 2004) menyatakan bahwa dalam setiap proses belajar, kemampuan mendapatkan ketrampilan-ketrampilan baru tergantung dari dua faktor, yaitu faktor internal dalam hal ini kematangan individu dan ekternal seperti stimulasi dari lingkungan. Faktor eksternal yang seringkali disorot berpengaruh terhadap perkembangan minat dan kebiasaan membaca seseorang adalah lingkungan keluarga dan lingkungan pendidikan, dalam hal ini guru dan perpustakaan. Perpustakaan menjadi fokus sentral dalam hal akses ke bahan bacaan karena masyarakat menaruh harapan besar pada lembaga ini untuk menyediakan informasi yang mereka butuhkan.

Membangun budaya literasi perlu kesadaran diri sendiri oleh masyarakat. Seperti membiasakan membaca buku, majalah, koran atau sumber informasi lainnya. Dan juga membiasakan kegiatan menulis seperti membuat catatan. Peran pemerintah juga dituntut besar, seperti memperkuat dunia pembukuan, memperbanyak taman bacaan atau perpustakaan, mensubsidi buku-buku,membantu distribusi buku serta yang paling penting yaitu menggalakkan budaya membaca.

Perpustakaan Nasional RI telah melakukan berbagai upaya dalam mengembangkan literasi. Selain upaya yang telah dilakukan masih banyak potensipontensi lain yang dapat digunakan untuk mengembangkan literasi. Beberapa diantaranya adalah potensi kewenangan, potensi sumber daya manusia, potensi teknologi informasi dan komunikasi, komunitas informasi dan kerjasama dengan pihak lain. Adanya pemahaman diri yang baik dan dengan memanfaatkan segala potensi yang ada, diharapkan Perpustakaan Nasional RI dapat mengambil peran penting dan dapat menjalankan dengan baik tugas untuk mengembangkan literasi informasi masyarakat sesuai dengan amanat konstitusi.

Selain itu, dikarenakan pemerintah sebagai pelaksana pendidikan di Indonesia telah mengupayakan generasi $\mathrm{Z}$ untuk gemar membaca, sebagai usaha 
untuk meningkatkan karakter dan budi pekerti siswa. Pemerintah mewajibkan sekolah, sebagai lembaga pendidikan untuk menanamkan budaya membaca. Sejak tahun 2015 pemerintah mecanangkan Gerakan Literasi Sekolah (GLS), yaitu kegiatan membaca 15 menit sebelum pelajaran dimulai, kegiatan ini untuk merangsang dan menumbuhkan minat baca siswa.

Studi kasus tentang rendahnya kemampuan membaca menulis masyarakat Indonesia, hingga kini, belum melahirkan pendekatan atau teori baru yang mampu mendongkrak dan memotivasi untuk menulis. Hal ini diperparah dengan mengglobalnya informasi melalui media visual yang berpengaruh terhadap pembangunan wacana literasi masyarakat Indonesia. Yang hendak kita bangun dengan sistem pendekatan terkini adalah sebuah masyarakat yang menyadari pentingnya belajar secara terus menerus dan menggunakan kegiatan membacamenulis (literasi).

Kebudayaan sangat erat hubungannya dengan pendidikan, sebab semua yang terkandung dalam kebudayaan diperoleh melalui proses belajar. Kebiasaan membaca dan menulis merupakan keterampilan yang dapat dipupuk dan dikembangkan menjadi suatu budaya. Dengan membaca, seseorang dapat memperoleh informasi, pengetahuan dan meningkatkan intelektual (Ane P, 2015).

Keberaksaraan atau yang biasa disebut dengan Literasi (literacy) kerap didaulat menjadi kunci yang mampu membuka pintu datangnya modernisasi, partisipasi, empati, demokratisasi, desentralisasi ilmu pengetahuan, perbaikan taraf hidup terutama ekonomi, serta kemajuan bangsa. Laporan UNESCO tahun 2005 berjudul Literacy for life menyebutkan ada hubungan erat antara illiteracy (ketidakberaksaraan) dan kemiskinan. Di banyak negara berangka kemiskinan tinggi seperti Bangladesh, Ethiopia, Ghana, India, Nepal, dan Mozambique, tingkat illiteracy-nya juga tinggi .

Merujuk pada sebuah perubahan dari keadaan yang kurang maju atau kurang berkembang ke arah yang lebih baik dengan harapan akan tercapai kehidupan masyarakat yang lebih maju, berkembang, dan makmur. Kemampuan untuk menyadari perasaan orang lain dan bertindak (sesuai) untuk membantu. Empati mencakup respon tersendiri terhadap perasaan orang lain, seperti rasa 
kasihan, kesedihan, rasa sakit. Suatu perubahan baik itu perlahan maupun secara cepat ke arah demokras. Pelimpahan kewenangan dari pemerintah pusat kepada pemerintah kabupaten/kota. Kewenangan yang dilimpahkan menyangkut pengaturan, pengurusan, pembinaan, dan pengawasan dan substansinya bisa melebar pada hal-hal menyangkut ilmu pengetahuan.

Mereka yang mempunyai kemampuan literasi (melek huruf secara fungsional), berkesempatan mencari dan memperoleh informasi yang bermanfaat dan berguna. Melalui informasi tersebut mereka mendapat pengetahuan baru yang kapan saja bisa digunakan dalam peningkatan taraf hidupnya. Seperti informasi untuk mengembangkan usaha. misalnya soal produk apa yang sedang dicari orang; mencari celah-celah pasar baru; dan sebagainya. Komunikasi dengan rekanan bisnis menjadi efektif dan hemat, terbukanya kesempatan mengikuti kursus atau pelatihan untuk meningkatkan kapasitas. Termasuk lincah menciptakan lowongan kerja bagi dirinya sendiri. Selain itu manfaat dari membaca dan menulis sangat banyak. Untuk mengetahui apa manfaatnya sebelum itu terlebih dahulu harus mengetahui apakah membaca tersebut suatu aktivitas atau hanya sekedar mengisi waktu luang. Kemudian harus mengetahui jenis bacaan apa yang dibaca, selanjutnya mengevaluasi bahan bacaan tersebut (Ridwan, 2004).

Budaya literasi merupakan cermin kemajuan bangsa. Para Antropolog bahasa, seperti Lucian Levy-Bruhl, Claude Levi-Strauss, Walter Ong, dan Jack Goody memandang literasi (bahasa) sebagai titik pangkal pembeda masyarakat primitif dari masyarakat "beradab". Menurut Levi-Strauss bahasa yang digunakan merefleksikan budaya atau perilaku manusia tersebut. Oleh karena itu ada kesamaan konsep antara bahasa dan budaya manusia. Ia berpendapat bahwa bahasa dapat digunakan untuk segala fenomena sosial dengan huruf dan tulisan. Dari berbagai konsep diatas, secara sederhana literasi dapat diartikan sebagai sebuah kemampuan membaca dan menulis serta kemampuan mengidentifikasi, mengurai dan memahami suatu masalah. Kita mengenalnya dengan melek aksara atau keberaksaraan. Ada bermacam-macam keberaksaraan atau literasi , misalnya literasi komputer (computer literacy), literasi media (media literacy) literasi teknologi (technology literacy), literasi ekonomi (economy literacy), literasi 
informasi (information literacy), bahkan ada literasi moral (moral literacy). Jadi, keberaksaraan atau literasi dapat diartikan melek teknologi, melek informasi, berpikir kritis, peka terhadap lingkungan, bahkan juga peka terhadap politik. Seorang dikatakan literat jika ia sudah bisa memahami sesuatu karena membaca informasi yang tepat dan melakukan sesuatu berdasarkan pemahamannya terhadap isi bacaan tersebut.

Gerakan literasi sekolah dikembangkan berdasarkan Permendikbud nomor 21/2015 tentang penumbuhan budi pekerti. Tujuan literasi sekolah adalah untuk membiasakan dan memotivasi siswa untuk membaca dan menulis guna menumbuhkan budi pekerti. Dalam jangka panjang diharapkan dapat menghasilkan anak-anak didik yang memiliki kemampuan literasi tinggi. Buku yang dibaca oleh guru maupun siswa merupakan nutrisi penting bagi langkah menumbuhkan karakter. Dalam rangka program literasi sekolah ini pemerintah Indonesia menyiapkan buku-buku yang didistribusikan ke sekolah-sekolah dengan tujuan agar dapat menumbuhkan budi pekerti siswa seperti buku cerita atau buku dongeng lokal, buku-buku yang menginspirasi seperti biografi, tokoh-tokoh lokal dan biografi anak bangsa yang berprestasi serta buku-buku sejarah yang dapat membentuk semangat kebangsaan atau cinta tanah air (Kemendikbud, 2014).

Untuk membangun budaya literasi, ada beberapa langkah yang bisa dilakukan oleh kita semua. Pertama, menumbuhkan minat baca sedini mungkin. Minat membaca diimulai dari keluarga. Orang tua wajib mendorong putra-putrinya untuk membaca banyak buku. Tak cukup itu, mereka seyogyanya memberi contoh. Mereka kudu terlebih dahulu membiasakan membaca. Mereka dapat menciptakan lingkungan yang mendukung menumbuhkan minat baca seperti ruang baca dengan buku bacaan. Sebab itu, membeli buku dijadikan kebutuhan primer yang harus dipenuhi dalam setiap bulannya. Menyisihkan uang bulanan untuk tujuan di atas menjadi pilihan orang tua bijak dalam membangun budaya literasi. Pembiasaan kegiatan membaca yang menyenangkan di keluarga ataupun di sekolah bertujuan untuk menumbuhkan minat terhadap bacaan dan terhadap kegiatan membaca, memahami bacaan dan mengaitkannya dengan pengalaman pribadi, berpikir kritis, 
dan mengolah kemampuan komunikasi secara kreatif melalui kegiatan menanggapi bacaan pengayaan (Anderson \& Krathwol, 2001).

Kemudian, sekolah memiliki peran penting. Di sekolah, anak-anak harus dibiasakan membaca. Guru memberi teladan. Mereka menanmkan kepada peserta didik kecintaan terhadap buku. Perpustakaan sekolah (diupayakan ada) sepantasnya dikelola dengan baik. Sehingga perpustakaan sekolah menjadi menarik untuk dikunjungi. Di sekolah, budaya tulis menulis dimulai. Peserta didik diajari menulis. Setiap pembelajaran, guru dapat menyisipkan kegiatan menulis atau mengarang. OSIS dilatih mengelola majalah dinding.

Kedua, subsidi buku. Di beberapa negara maju, pembelian buku memperoleh subsidi dari pemerintah. Sebagai nagara berkembang yang mengejar ketertinggalan di berbagai sektor, tak salah bila Pemerintah Indonesia mengusahakan hal tersebut. Subsidi akan membantu masyarakat dalam memiliki serta membaca buku.

Ketiga mengoptimalkan peran perpustakaan daerah. Keberadaan perpustakaan daerah selama ini belum menunjukkan perannya dalam masyarakat. Keberadaanya antara ada dan tiada. Ini terkait dengan pengelolaan dan pelayanan belum maksimal. Koleksi buku perlu ditambah. Perpustakaan daerah diupayakan membuat terobosan dengan kegiatan menarik seperti lomba menulis, lomba baca puisi, atau lainnya.

Keempat, menghargai karya tulis. Bangsa ini musti belajar mennghargai karya orang lain. Dan karya tulis sepatutnya memperoleh tempat khusus, melebihi karya lain. Pemerintah dituntut memilki perhatian khusus pada para penulis. Pemerintah harus mendorong dan menumbuhkan kegiatan penulisan juga penelitian (http://amirudinmahmud.blogspot.co.id).

Kelima, Budaya literasi sejatinya membutuhkan dukungan politik dari Pemerintah dan DPR. Budaya literasi berkaitan dengan masa depan bangsa, karena itu perlu mendapat perhatian serius. Selama ini dukungan dari pemerintah masih bersifat temporer. Baru ada perhatian jika peringatan hari-hari tertentu seperti perayaan Hari Buku Nasional beberapa bulan yang lalu, yang pelaksanaannyapun hampir sama seperti tahun-tahun sebelumnya, berlangsung sepi, baik secara 
seremonial maupun subtansial. Tidak ada kegiatan yang benar-benar menghentak atau menyulut kesadaran baru tentang buku, tentang budaya literasi.

\section{SIMPULAN}

Penelitian ini dapat disimpulkan bahwa factor pertama yang mempengaruhi budaya/kebiasaan literasi/kemampuan membaca pada diri seseorang yaitu pada factor internal berupa diri sendiri. Faktor kedua yaitu faktor ekternal seperti stimulasi dari lingkunga keluarga dan lingkungan pendidikan, dalam hal ini guru dan perpustakaan. Kebangkitan budaya literasi bangsa Indonesia tidak lepas dari niat masing-masing dan membangun pola kebiasaan dalam membaca dan menulis dari keluarga. Kemudian sekolah seyogyanya mengambil peran penting menyiapakan generasi gemar baca dan menulis. Sementara itu, pemerintah harus sudah mulai mengalokasikan anggaran subsidi buku untuk rakyat. Untuk membangun budaya literasi, ada beberapa langkah yang bisa dilakukan oleh kita semua. Pertama, menumbuhkan minat baca sedini mungkin. Kedua, subsidi buku. Ketiga mengoptimalkan peran perpustakaan daerah. Keempat, menghargai karya tulis. Kelima, Budaya literasi sejatinya membutuhkan dukungan politik dari Pemerintah dan DPR.

\section{REFERENSI}

Ahimsa-Putra, H S. 2001. Strukturalisme Lévi-Strauss Mitos dan Karya Sastra. Yogyakarta: Galang Press.

Anderson, L.W., dan Krathwohl, D.R. 2001. A Taxonomy for Learning, Teaching, and Assesing; A revision of Bloom's Taxonomy of Education Objectives New York: Addison Wesley Lonman Inc.

Ane Permatasari. 2015. Membangun Kualitas Bangsa dengan Budaya Literasi. Proseding Seminar Nasional Bulan Bahasa UNIB 2015. Yogyakarta.

Ferrinadewi, Erna \& Didit Darmawan. 2004. Perilaku Konsumen: Analisis Model Keputusan. Yogyakarta: Penerbitan Universitas atmajaya.

Hendro Prasetyo dan M.Habiburrahman. 2015. Budaya Literasi Kunci Optimalisasi Pembelajaran Bahasa Indonesia yang berkualitas pada era MEA. Mataram. Seminar Nasional Penidikan Bahasa Indonesia. 
Julia. 2011. Pengaruh Budaya Literasi terhadap Oraliti imur dalam Transmisi Musik amelan di Lingkungan Universitas Pendidikan Indonesia. Bandung: UPI. Makalah yang disajikan dalam Konferensi Internasional Pendidikan Dasar II UPI 28-29 Oktober 2011.

Kamus Besar Bahasa Indonesia. 2008. Jakarta: Gramedia.

Kemendikbud, UNESA, dan Eureka. 2014. Gerakan Literasi Sekolah. (menjadikan Indonesia sebagai negara berbudaya literasi tinggi setaraf dengan negara maju). Jakarta: Kemendikbud.

Permendikbud Nomor 21 tahun 2015. Penerapan Budi Pekerti. 2015. Jakarta: Kemendikbud.

Ridwan. 2004. Perpustakaan : Energi Pembangunan Bangsa. Medan: Pustaka.

The Jakarta Post, 12 Maret 2016 (diunduh pada tanggal 4 Julii 2017, pukul 11.00 WIB).http://amirudinmahmud.blogspot.co.id (diunduh pada tanggal 4 Juli 2017, pukul 12.15 WIB. 